\title{
STUDI DESKRIPTIF PASIEN TB MDR DI SULAWESI SELATAN
}

\author{
A Descriptive Study Of Multidrug Resistent Tuberculosis Patients In South Sulawesi
}

\author{
Ikes Dwiastuti, Nur Asphina R Djano \\ STIKES Mega Buana Palopo \\ Email : ikesdwiastuti@gmail.com
}

\begin{abstract}
$M D R-T B$ is a disease that is resistant to two of the most effective anti-TB drugs, rifampicin and isoniazid, and is one that inhibits TB protection. The purpose of this study was to provide an overview of the characteristics, status of diabetes mellitus, nutritional status, and conversion status of MDR TB patients in South Sulawesi in 2019. This study used a descriptive design. The study was conducted at the Labuang Baji District Hospital in Makassar City from April-June 2019. The sample in this study was a portion of Pulmonary TB patients. The results obtained by the average age of respondents is 43.4 years; There were $60.2 \%$ of male patients and $39.8 \%$ of female patients; Most types of patients relapsed as much as $44.7 \%$ and $80.7 \%$ were patients who had a history of previous treatment. As many as $27.5 \%$ of patients were positive suffering from DM; Patients who have high nutritional status are $62.2 \%$ and only $89.6 \%$ of patients require sputum conversion.
\end{abstract}

Keywords : MDR TB; Diabetes Mellitus; Nutritional Status; Sputum Conversion

\begin{abstract}
Abstrak
TB-MDR merupakan penyakit TB yang resisten terhadap dua obat anti-TB yang paling efektif yakni rifampisin dan isoniazid dan menjadi salah satu ancaman dalam pengendalian TB. Tujuan penelitian ini adalah untuk mengetahui gambaran tentang karakteristik, status diabetes mellitus, status gizi, dan status konversi pasien TB MDR di Sulawesi Selatan Tahun 2019. Penelitian ini menggunakan desain deskriptif. Penelitian dilakukan di RSUD Labuang Baji Kota Makassar sejak bulan April-Juni 2019. Sampel dalam penelitian ini adalah sebagian pasien TB MDR yang menjalani pengobatan MDR paduan jangka pendek (Short-term Regimen) sejak tahun 2018 sebanyak 114 pasien yang diperoleh dengan teknik purposive sampling. Hasil penelitian diperoleh yakni rata-rata umur responden yakni 43,4 tahun; terdapat sebanyak 60,2\% pasien laki-laki dan 39,8\% pasien perempuan; sebagian besar tipe pasien adalah kambuh sebanyak $44,7 \%$ dan $80,7 \%$ adalah pasien yang memiliki riwayat pengobatan sebelumnya. Terdapat sebanyak $27,5 \%$ pasien yang positif menderita DM; pasien yang memiliki status gizi kurus terdapat sebanyak $62,2 \%$ dan hanya $89,6 \%$ pasien yang mengalami konversi sputum.
\end{abstract}

Kata kunci : TB MDR; Diabetes Mellitus; Status Gizi; Konversi Sputum 


\section{PENDAHULUAN}

TB Resisten Obat merupakan masalah kesehatan masyarakat dan menjadi ancaman dalam pengendalian TB secara Global saat ini (Kementrian Kesehatan RI, 2018). Terdapat tiga kategori utama yang digunakan untuk surveilans dan pengobatan TB Resisten Obat yakni TB-MDR, TB-RR dan TBXDR. TB-MDR merupakan penyakit TB yang resisten terhadap dua obat anti-TB yang paling efektif yakni rifampisin dan isoniazid (World Health Organization, 2017).

WHO secara global mengestimasikan kasus TBMDR/RR pada Tahun 2017 sebanyak 558.000 (range, 483.000-639.000) kasus insiden, 82\% (460.000-560.000) diantaranya diestimasikan kasus TB-MDR. Sedangkan kematian akibat TB-MDR/RR pada tahun 2017 yakni berkisar 230.000 (range, 140.000-310.000). Negara dengan jumlah kasus TB-MDR/RR terbesar yakni Cina (47\% dari kasus secara global), India, dan Federasi Rusia. Sedangkan Indonesia menempati urutan ketujuh setelah Nigeria dengan jumlah kasus pada tahun 2017 yakni 23.000 (range, 16.000-31.000) kasus insiden (World Health Organization, 2018).

Tatalaksana pengobatan pasien TB Resisten Obat di Indonesia telah dilaksanakan sejak tahun 2009. Pengobatan TB Resisten Obat telah ditetapkan dalam Program Pengendalian TB Nasional (Kementrian Kesehatan RI, 2018). Di Sulawesi Selatan, RSUD Labuang Baji merupakan rumah sakit rujukan pengobatan pasien TB-MDR/RR (Kementerian Kesehatan RI, 2011). Berdasarkan data dari RSUD Labuang Baji pada tahun 2018, terdapat sebanyak 275 kasus insiden dengan jumlah kematian akibat TB-MDR sebanyak 20 kasus yang terlapor (Rekam Medis RSUD Labuang Baji, 2018). Adapun tujuan penelitian ini adalah untuk mengetahui gambaran tentang karakteristik, status diabetes mellitus, status gizi, dan status konversi pasien TB MDR di Sulawesi Selatan Tahun 2019.

\section{BAHAN DAN METODE}

Penelitian ini menggunakan pendekatan kuantitatif dengan desain deskriptif yang bertujuan untuk memberikan gambaran tentang karakteristik, status diabetes mellitus, status gizi, dan status konversi pasien TB MDR di RSUD Labuang Baji Kota Makassar. Penelitian dilakukan di RSUD Labuang Baji Kota Makassar sejak bulan April-Juni 2019. Populasi dalam penelitian ini adalah seluruh pasien
TB MDR yang menjalani pengobatan MDR paduan jangka pendek (Short-term Regimen) sejak tahun 2018 yakni sebanyak 342 pasien. Adapun sampel dalam penelitian ini yakni sebanyak 114 pasien yang diperoleh dengan teknik purposive sampling. Adapun kriteria eksklusi dalam penelitian ini adalah pasien yang Form TB 01 MDR tidak ditemukan atau rusak dan sudah tidak bisa terbaca.

Pengumpulan data sekunder dengan menggunakan form penelitian yang mengikuti Form TB 01 MDR dari Kementerian Kesehatan RI. Data yang telah diperoleh dalam penelitian ini yakni karakteristik responden (nama, umur, jenis kelamin, status parut BCG), Tipe pasien, riwayat pengobatan sebelumnya, status konversi, status diabetes mellitus, berat badan, tinggi badan, dan status IMT. Data yang telah diperoleh kemudian diolah secara deskriptif menggunakan SPSS untuk mendapatkan gambaran pasien TB MDR di Provinsi Sulawesi Selatan Tahun 2018-2019.

\section{HASIL DAN PEMBAHASAN}

Tabel 1 menunjukkan distribusi pasien TB MDR berdasarkan karakteristik pasien diantaranya ratarata umur pasien adalah 43,4 tahun $(S D= \pm 15,2)$. Dari 113 pasien TB MDR diketahui terdapat sebanyak 60,2\% laki-laki dan 39,8\% perempuan. Status parut BCG merupakan salah satu variabel yang terdapat di dalam form 01 TB MDR, dari 80 pasien TB MDR terdapat $48,8 \%$ pasien yang memiliki tanda jelas pada parut BCG, 43,8\% yang tidak ada parut BCG dan terdapat $7,5 \%$ yang memiliki tanda parut BCG meragukan. Sedangkan dari 114 pasien diketahui terdapat $80,7 \%$ pasien yang memiliki riwayat pengobatan sebelumnya dan $44,7 \%$ merupakan pasien yang kambuh.

Berdasarkan tabel 2 diketahui distribusi pasien TB MDR berdasarkan status konversi, status diabetes mellitus dan status gizi. Dari 43 pasien terdapat sebanyak $89,6 \%$ yang mengalami konversi sputum. Dari 109 pasien terdapat 27,5\% pasien yang positif menderita diabetes mellitus. Dan terdapat sebanyak $62,2 \%$ pasien yang status gizinya kurus.

Penelitian ini menemukan bahwa rata-rata umur pasien TB MDR adalah $43,4( \pm 15,2)$ tahun. Beberapa penelitian juga menunjukkan hasil yang serupa yakni penelitian Reviono dkk (2014) menemukan TB MDR lebih banyak terjadi pada pasien yang berumur $>41$ tahun (Reviono et al., 2013). 
Tabel 1. Distribusi Pasien TB MDR berdasarkan karakteristik

\begin{tabular}{lccc}
\hline Karakteristik & $\mathbf{n}$ & Mean & SD \\
\hline Umur (Tahun) & 112 & 43,4 & $\pm 15,2$ \\
\hline Karakteristik & $\mathbf{n}$ & Frekuensi (f) & Persentase (\%) \\
\hline Jenis kelamin & 113 & & \\
$\quad$ Laki-laki & & 68 & 60,2 \\
$\quad$ Perempuan & & 45 & 39,8 \\
Status Parut BCG & 80 & 39 & 48,8 \\
$\quad$ Jelas & & 35 & 43,8 \\
$\quad$ Tidak Ada & & 6 & 7,5 \\
$\quad$ Meragukan & 114 & 92 & 80,7 \\
Riwayat Pengobatan Sebelumnya & & 22 & 19,2 \\
Ada & & & 21,1 \\
Tidak ada & & 24 & 44,7 \\
Tipe pasien & 114 & 51 & 12,3 \\
Baru & & 14 & 20,2 \\
Kambuh & & 23 & 0,9 \\
Defaulter & 1 & 0,9 \\
Gagal K1 & & 1 & \\
Gagal K2 & & & \\
Lain-lain & & & \\
\hline
\end{tabular}

Tabel 2. Distribusi Pasien TB MDR berdasarkan Variabel Penelitian

\begin{tabular}{lccc}
\hline Variabel & $\mathbf{n}$ & Frekuensi (f) & Persentase (\%) \\
\hline Status Konversi & 48 & & \\
$\quad$ Ya & & 43 & 89,6 \\
$\quad$ Tidak & 109 & 5 & 10,4 \\
Status Diabetes Mellitus & & 30 & 27,5 \\
$\quad$ Positif & & 79 & 72,5 \\
$\quad$ Negatif & 82 & 51 & 62,2 \\
Status Gizi & & 31 & 37,8 \\
$\quad$ Kurus & & & \\
$\quad$ Normal &
\end{tabular}

Usia produktif memiliki risiko lebih besar mengalami kejadian TB MDR disebabkan karena lebih banyak beraktivitas selain itu kemungkinan lain disebabkan pengobatan yang tidak tepat atau tidak lengkap di masa lalu (Bijawati, Amansyah and Nurbiah, 2018; Kawatsu et al., 2018).

Variabel jenis kelamin juga dilaporkan menjadi salah satu faktor risiko TB MDR dalam beberapa penelitian. Sebagian besar pasien TB MDR dalam penelitian ini adalah laki-laki sebanyak 60,2\% (68 pasien dari 113 pasien). Penelitian Feleke M, dkk di Ethiopia menemukan sebanyak $64,5 \%$ pasien TB MDR adalah laki-laki (Mekonnen et al., 2015). Lakilaki memiliki kecenderungan yang lebih tinggi untuk tidak mematuhi pengobatan anti-TB dibandingkan perempuan, sehingga meningkatkan risiko TB MDR (Heunis et al., 2014).

Pada penelitian ini juga mendapatkan hasil terkait status parut BCG yakni terdapat sebanyak $43,8 \%$ pasien yang tidak memiliki parut BCG dan $48,8 \%$ memiliki tanda yang jelas pada parut BCG. Penelitian yang dilakukan oleh Putri P, dkk menemukan adanya hubungan antara riwayat BCG dengan kejadian TB MDR (Pamungkas, Rahardjo and Murti, 2018). Karena vaksin BCG dapat menurunkan risiko TB (Seaworth et al., 2014).

Peluang kejadian TB MDR lebih besar pada pasien TB MDR yang telah memiliki riwayat pengobatan sebelumnya. Pada penelitian ini diketahui terdapat $80,7 \%$ yang memiliki riwayat pengobatan sebelumnya dan terdapat sebanyak 
$44,7 \%$ merupakan pasien yang kambuh. Dalam penelitian Muluken D, dkk mengidentifikasi bahwa riwayat pengobatan TB sebelumnya merupakan penentu utama dalam kejadian TB MDR (Dessalegn et al., 2016).

Status konversi sputum BTA menjadi penentu dalam menentukan lama pengobatan dan hasil akhir pengobatan pada pasien TB MDR. Pada pengobatan MDR dengan paduan STR total pengobatan adalah 911 bulan, dimana bila belum terjadi konversi sputum BTA pada bulan ke-4 pengobatan tahap awal diperpanjang sampai bulan ke-5 atau ke-6 (Kementrian Kesehatan RI, 2018). Tingkat konversi pada penelitian ini cukup besar yakni 89,6\% .

Pengobatan TB paru menjadi lebih sulit sejalan dengan sulitnya pengendalian kadar gula darah pasien. Dalam penelitian ini, diketahui terdapat 27,5\% pasien TB MDR yang memiliki riwayat penyakit diabetes mellitus. Sedangkan pada penelitian Abu Bakar S, dkk di Bangladesh menemukan sebanyak 11,5\% pasien TB MDR yang menderita DM (Siddik et al., 2018). Pasien dengan diabetes mellitus memiliki gangguan kekebalan dibandingkan dengan orang yang sehat, dan diabetes dapat meningkatkan efek samping dari obat anti-TB (Ketema, Muchie and Andargie, 2019).

Status gizi merupakan cerminan ukuran terpenuhinya kebutuhan gizi yang didapatkan dari asupan dan penggunaan gizi oleh tubuh (Iqbal and Puspaningtyas, 2019). Pada penelitian ini diketahui status gizi penderita TB MDR paling banyak dalam kategori kurus yakni $62,2 \%$ dan yang memiliki kategori status gizi normal yakni 37,8\%.

\section{KESIMPULAN DAN SARAN}

Berdasarkan hasil penelitian diketahui bahwa rata-rata umur responden yakni 43,4 tahun; terdapat sebanyak 60,2\% pasien laki-laki dan 39,8\% pasien perempuan; sebagian besar tipe pasien adalah kambuh sebanyak 44,7\% dan $80,7 \%$ adalah pasien yang memiliki riwayat pengobatan sebelumnya. Terdapat sebanyak $27,5 \%$ pasien yang positif menderita DM; pasien yang memiliki status gizi kurus terdapat sebanyak 62,2\% dan hanya $89,6 \%$ pasien yang mengalami konversi sputum.

\section{Ucapan Terima Kasih}

Sumber pendanaan penelitian ini yaitu Direktorat Riset dan Pengabdian Masyarakat,
Direktorat Jenderal Penguatan Riset dan Pengembangan Kementerian Riset, Teknologi, dan Pendidikan Tinggi Republik Indonesia. Ucapan terima kasih juga disampaikan kepada dr. Jamaluddin M di Pusat Infeksi Paru RSUD Labuang Baji yang telah memberikan saran dan masukan bagi Peneliti selama proses penelitian.

\section{DAFTAR PUSTAKA}

Bijawati, E., Amansyah, M. and Nurbiah (2018) 'Faktor risiko pengobatan pasien multidrug resistance tuberculosis (mdr-tb) di RSUD Labuang Baji Kota Makassar tahun 2017', Jurnal Nasional Ilmu Kesehatan, 1, pp. 1-17.

Dessalegn, M. et al. (2016) 'Predictors of multidrug resistant tuberculosis among adult patients at Saint Peter Hospital Addis Ababa, Ethiopia', The Pan African medical journal, 25(Supp 2), p. 5. doi: 10.11604/pamj.supp.2016.25.2.9203.

Heunis, J. C. et al. (2014) 'Sex-related trends in nonconversion of new smear-positive tuberculosis patients in the Free State, South Africa', Public Health Action, 4(1), pp. 66-71. doi: 10.5588/pha.13.0108.

Iqbal, M. and Puspaningtyas, D. E. (2019) Penilaian Status Gizi ABCD. Cetakan Ke. Jakarta: Salemba Medika.

Kawatsu, L. et al. (2018) 'Treatment outcome of multidrug-resistant tuberculosis in Japan - the first cross-sectional study of Japan tuberculosis surveillance data', BMC Infectious Diseases. BMC Infectious Diseases, 18(1), pp. 1-7. doi: 10.1186/s12879-018-3353-9.

Kementerian Kesehatan RI (2011) 'Rencana Aksi Nasional Programmatic Management of Drug resistance Tuberculosis Pengendalian Tuberkulosis Indonesia: 2011-2014', Kementerian Kesehatan Republik Indonesia, pp. 618.

Kementrian Kesehatan RI (2018) Pedoman Nasional Pengobatan Tuberkulosis Resisten Obat.

Ketema, D. B., Muchie, K. F. and Andargie, A. A. (2019) 'Time to poor treatment outcome and its predictors among drug-resistant tuberculosis patients on second-line anti-Tuberculosis treatment in Amhara region, Ethiopia: Retrospective cohort study', BMC Public Health. BMC Public Health, 19(1), pp. 1-10. doi: 10.1186/s12889-019-7838-2. 
Mekonnen, F. et al. (2015) 'Multidrug resistant tuberculosis: Prevalence and risk factors in districts of metema and west armachiho, Northwest Ethiopia', BMC Infectious Diseases, 15(1). doi: 10.1186/s12879-015-1202-7.

Pamungkas, P., Rahardjo, S. S. and Murti, B. (2018) 'Evaluation of Multi-Drug Resistant Tuberculosis Predictor Index in Surakarta, Central Java', Journal of Epidemiology and Public Health, 03(02), pp. 263-276. doi: 10.26911/jepublichealth.2018.03.02.06.

Rekam Medis, R. L. B. (2018) Data TB MDR. Makassar.

Reviono et al. (2013) 'Multidrug Resistant Tuberculosis ( MDR-TB ): Tinjauan Epidemiologi dan Faktor Risiko Efek Samping Obat Anti Tuberkulosis Multidrug Resistant Tuberculosis ( MDR-TB ): Epidemiologic Review and Adverse Events Risk Factors of Anti Tuberculosis Drugs', 46(4), pp. 189-196.
Seaworth, B. J. et al. (2014) 'Multidrug-resistant tuberculosis. Recommendations for reducing risk during travel for healthcare and humanitarian work', Annals of the American Thoracic Society, 11(3), pp. 286-295. doi: 10.1513/AnnalsATS.201309-312PS.

Siddik, A. B. et al. (2018) ‘Descriptive Epidemiology of Multidrug Resistance Tuberculosis (MDRTB) in Bangladesh', Journal of Tuberculosis Research, 06(04), pp. 292-301. doi: $10.4236 /$ jtr.2018.64026.

World Health Organization (2017) Global Tuberculosis Report. Geneva: WHO Press.

World Health Organization (2018) Global Tuberculosis Report 2018. Geneva: WHO. 